\title{
Toward a Comprehensive Set of Metrics for Knowledge Transfer
}

\author{
ANTHONY ARUNDEL AND NORDINE ES-SADKI
}

\subsection{Introduction}

The commercialization of knowledge produced by public research organizations, consisting of universities and public research institutes, requires the transfer of knowledge to firms, government entities, or nonprofit organizations and the application of this knowledge to products and processes. This transfer process occurs through a number of channels, but, as noted in Chapter 2, most research on knowledge transfer from public research organizations to other organizations uses metrics for IP-mediated forms of knowledge transfer, for instance, licenses for codified intellectual property such as patents. This is partly because research on IP-mediated knowledge transfer is facilitated by the electronic "trail" left by IP. This ensures that the activities and outputs of IP are easier to identify than other methods of knowledge transfer.

Six metrics for IP-mediated knowledge transfer are often collected by private or public sector organizations in high-income countries from surveys of knowledge transfer offices (KTOs): the number of invention disclosures, patent applications, patent grants, licenses, and startups established, plus the total amount of license revenue earned by the public research organization. In addition, many of these surveys also collect data on the number of research agreements with firms, which can result in knowledge transferred by IP or through other channels.

Table 12.1 identifies the collection of data on these knowledge transfer metrics by each of the six case study countries covered in this book. The only metrics that have been collected for a large sample of public research organizations in all six countries are the number of patent applications and patent grants. In most countries, the collection of data for other metrics has been sporadic, with only the United Kingdom collecting 
Table 12.1 Data collected for IP-mediated knowledge transfer plus research agreements at the institutional level (results for six countries)

\begin{tabular}{|c|c|c|c|c|c|c|}
\hline & China & Brazil & $\begin{array}{l}\text { South } \\
\text { Africa }\end{array}$ & UK & Korea & Germany 1 \\
\hline $\begin{array}{l}\text { Number of invention } \\
\text { disclosures }\end{array}$ & & & $\checkmark$ & $\checkmark$ & $\checkmark$ & \\
\hline $\begin{array}{l}\text { Number of patent } \\
\text { applications }\end{array}$ & $\checkmark$ & $\checkmark$ & $\checkmark$ & $\checkmark$ & $\checkmark$ & $\checkmark$ \\
\hline $\begin{array}{l}\text { Number of patent } \\
\text { grants }\end{array}$ & $\checkmark$ & $\checkmark$ & $\checkmark$ & $\checkmark$ & $\checkmark$ & $\checkmark$ \\
\hline $\begin{array}{l}\text { Number of licenses with } \\
\text { firms }\end{array}$ & & $\checkmark$ & $\checkmark$ & $\checkmark$ & $\checkmark$ & \\
\hline $\begin{array}{l}\text { Total license income } \\
\text { earned }\end{array}$ & & $\checkmark$ & $\checkmark$ & $\checkmark$ & $\checkmark$ & \\
\hline $\begin{array}{l}\text { Number of startups } \\
\text { using institutional IP }\end{array}$ & & & $\checkmark$ & $\checkmark$ & $\checkmark$ & $\checkmark$ \\
\hline $\begin{array}{l}\text { Number of research } \\
\text { agreements with } \\
\text { firms }\end{array}$ & & $\checkmark$ & & $\checkmark$ & & \\
\hline
\end{tabular}

Source: National experts responding to a WIPO survey on data collection

${ }^{1}$ Data have been collected by private-sector organizations for all seven metrics for a selected number of leading public research organizations.

these data for all universities over the long term. ${ }^{1}$ Additionally, privatesector organizations that represent knowledge transfer professionals such as RedOTRI (Spain), NetVal (Italy), and the umbrella organization ASTP (formerly ASTP-ProTon) collect relevant data for these metrics in Germany and other high-income countries, but with the exception of Spain and Italy, less than 50 percent of universities and public research institutes are covered (Finne et al. 2009). Since these metrics are of high value for benchmarking outcome performance and monitoring the use of IP to transfer knowledge, all countries should ideally collect these metrics on a regular basis for all public research organizations, or at the

1 The Danish Agency for Science, Technology and Innovation (DASTI), currently part of the Ministry of Higher Education in Science in Denmark, collected knowledge transfer data for all Danish universities between 2000 and 2013. Réseau SATT in France, an umbrella organization of regional networks that provide support on knowledge transfer for universities in their region, has collected relevant data, but not consistently. 
minimum for research-intensive public research organizations, as done by the Association of University Technology Managers (AUTM) in the United States of America (U.S.) and in Canada (AUTM 2016, 2017).

A major issue is the international comparability of knowledge transfer metrics. Comparable metrics are of value for benchmarking performance and for policy learning through the use of econometric analysis to evaluate the effects of inputs and outputs on knowledge transfer. For instance, policymakers in one country or region can learn from evaluations of the effects of knowledge transfer activities on outcomes in countries or regions with similar levels of economic development or similar industrial structures. As discussed in Chapter 2, the de facto definitions of IP-mediated knowledge transfer have been set by the AUTM. China collects data on activities such as "knowledge transfer" and university enterprises that are not fully comparable with the AUTM definitions. As some of these metrics are useful for Chinese policy, international comparability would require China to collect additional metrics using the AUTM definitions.

A reliance on metrics for IP-mediated knowledge transfer creates two substantial issues. First, measurement implies that the measured activity is of high value, while unmeasured activities are of low value. Consequently, the act of measuring IP sends a strong signal to university managers (and policymakers) that more university IP is desirable, while other activities to transfer knowledge are erroneously viewed as unimportant. One consequence is that the types of metrics that are collected can affect the distribution of public funding and the ranking of universities. In the United Kingdom this resulted in a dispute over the types of knowledge transfer metrics to be collected between the Russel Group of research universities, which benefited from a narrow focus on IP metrics, and a group of younger universities, established after 1992, that wanted knowledge transfer metrics to cover a broader number of activities (Lockett et al. 2015).

Second, policies and practices to promote knowledge transfer must ensure that all aspects of a knowledge transfer system are functioning. There is a large and diverse variety of channels for transferring knowledge that are not covered by the seven commonly used metrics and which have been identified as important conduits for knowledge transfer in Chapter 11 and other research (Walshok and Shapiro 2014). Bekkers et al. (2008) identify twenty-one channels, ranging from publications to personal contacts. In particular, metrics for IP-mediated knowledge transfer do not capture the transfer of tacit knowledge, which requires 
direct, personal contact between the provider and the recipient of the knowledge. These personal contacts, for instance, through staff exchanges between firms and public research organizations, play a vital role in the transfer of knowledge for breakthrough discoveries (Bekkers et al. 2008). One concern is that a policy focus on supporting IP-mediated channels can unintentionally interfere with the use of other knowledge transfer channels (Rosli and Rossi 2014; Czarnitzki et al. 2016; Veugelers 2016). The combination of informal and formal channels has been found to have a positive effect on innovation outcomes (Link et al. 2007; Siegel et al. 2003; Grimpe and Hussinger 2013) and could be especially important to the performance of spinoffs (Hayer 2016).

The economic relevance of a broader set of knowledge transfer metrics is well established, with research from both the United Kingdom and China (see Chapters 4 and 8), showing that non-IP-mediated knowledge transfer activities are considerably more important than IP-mediated channels, as proxied by the amount of income earned by public research organizations from IP versus other knowledge transfer methods. For example, in 2015-16 all universities in the United Kingdom combined earned $£ 4.2$ billion from all knowledge transfer activities, of which only $£ 176$ million (4.2 percent) was due to IP licensing (HEFCE 2017).

These limitations with metrics for IP-mediated knowledge transfer have been recognized for some time (Holi et al. 2008; Jensen et al. 2009; Lockett et al. 2015). They may be particularly important for middle-income countries that have enacted policies to replicate the American Bayh-Dole Act for IP (see Chapter 11), while neglecting policies to support other forms of knowledge transfer. Based on the country case studies and other research, Chapter 10 argues that middle-income countries would benefit from knowledge transfer policies to increase incentives for public research organizations to interact with firms and policies to increase the absorptive capacities of firms to use and apply knowledge produced by public research organizations. Both of these goals can be enhanced by policies that support the full range of knowledge transfer channels, based on evidence showing that the optimal channel varies by firm capabilities and the characteristics of the knowledge to be transferred (Bekkers et al. 2008; Belitski et al. 2019).

In addition to data on IP-mediated knowledge transfer, surveys of KTOs or other administrative units within a public research organization can collect data on other formal channels such as contract and collaborative research with firms or government organizations. However, other knowledge transfer metrics need to be collected from academics and 
firms in order to overcome a lack of knowledge on the part of KTO staff. Large-scale surveys in Europe show that KTO managers are not always able to report research agreements with firms, as some of these are managed outside KTO administration (Barjak et al. 2015). Furthermore, KTO staff can be unaware of important knowledge transfer activities via publications or through informal channels. Freitas et al. (2013) estimates that approximately 50 percent of knowledge transfer from public research organizations in a province of Northern Italy occurred through personal interactions.

There can also be large differences in the perceptions of KTO managers, academics, and firm managers on the factors that support or act as barriers to knowledge transfer. Siegel et al. (2003) surveyed KTO managers, academics, and firm managers to obtain their opinions on barriers to knowledge transfer. They found large and statistically significant differences among these three groups that were often self-serving. For example, KTO managers did not find university bureaucracy and inflexibility to be important barriers, but both academics and firm managers did. Relying on the perceptions of only one of these three key actors could result in misleading recommendations for how to improve knowledge transfer.

This chapter discusses and identifies data for measuring non-IPmediated methods of knowledge transfer, as well as metrics for the use of policies and practices to support knowledge transfer. The latter are required to be able to assess policy effectiveness. The purpose is to provide data for all major channels of knowledge transfer in addition to IP-mediated channels, as covered in Chapter 2. Many of the types of data discussed in this chapter also meet statistical requirements to be specific, measurable, reliable, timely, and cost-effective (Jensen et al. 2009). In addition, the chapter discusses a limited number of metrics that can be used to assess the systemic impacts of knowledge transfer, including impacts from IP licensing. Metrics for impacts are, unfortunately, considerably more difficult and costly to obtain than metrics for activities.

In addition to collecting data from KTOs (or university administrations responsible for knowledge transfer), data on knowledge transfer activities need to be collected through surveys of scientists and other academics employed by public research organizations that create knowledge, and the firms that are the intended recipient of knowledge. Surveys of academics and firms are the best method for collecting data on informal knowledge transfer channels (Sigurdson et al. 2015). A fourth method is to use publicly available data, for instance, on patenting or publications or through web-scraping techniques. The types of data that can be collected through each of these 
methods and their limitations are discussed below. Of note, this chapter follows the Oslo Manual (OECD/Eurostat 2018) by identifying lists of topics to be covered by data collection instead of providing specific questions for surveys, with the exception of questions for policies and practices to promote knowledge transfer. ${ }^{2}$

\subsection{Data from KTOs and University Administrations}

The AUTM licensing activity surveys have served as the baseline model for data collection from KTOs, but the questions are largely limited to IPmediated knowledge transfer outcomes and activities. ${ }^{3}$ The British Higher Education-Business and Community Interaction (HE-BCI) survey, sent to KTOs or other responsible administrative units within British universities, covers a broader range of formal knowledge transfer activities that are not always part of IP licensing, although some of these activities can contribute to IP licensing (Holi et al. 2008; Rossi and Rosli 2015). Part A of the survey collects data on policies and practices for knowledge transfer, including the strategic goals for these activities, priorities by region, staff incentives, in-house capabilities for managing IP, and practices for supporting spinoffs and startups. Part B of the survey collects financial data on income earned by universities for five formal knowledge transfer activities: collaborative research, contract research, consultancies, facilities and equipment-related services, and professional development and continuing education. ${ }^{4}$ Income data are obtained by the source of funding: government, businesses, and third-sector organizations. In addition, business funding is separated into SMEs and large businesses for all activities other than collaborative research. ${ }^{5}$ KTO data are useful for benchmarking and monitoring formal knowledge transfer

2 Specific questions are not provided because questions need to be carefully developed following agreed international definitions and to undergo cognitive testing through faceto-face interviews with potential survey respondents. First drafts of questions usually go through substantial changes before they are ready for use. The examples of questions for policy practice should not be used without further testing.

${ }^{3}$ See https://autm.net/surveys-and-tools.

4 The questions used in Part A are available at www.hesa.ac.uk/collection/c18032/heb ci_a_questions. The questions for Part B are available as downloadable templates for individual years, with the templates for the 2017-18 survey available here: www .hesa.ac.uk/collection/c17032.

5 A sixth category of regeneration and development programs is not included here because it is not relevant to many countries. 
outcomes such as different forms of income earned by universities and public research institutes and for policy evaluation.

The HE-BCI survey is a useful model for collecting data on a full range of formal knowledge activities for all countries and was proposed for implementation by Australia (Jensen et al. 2009). To succeed, public research organizations need to invest in accounting systems to collect financial data for specific income sources. As this can be costly, a governmental authority may need to provide an incentive to compel universities to collect these data. The United Kingdom is able to collect these data for almost all universities because compliance with the HE-BCI reporting requirements is necessary for eligibility for one of the UK government's funding programs. A similar approach could be useful in other countries that provide publicly funded research grants to public research organizations.

\subsubsection{Measuring the Benefits of Knowledge Transfer to Public Research Organizations}

The financial benefit to public research organizations is usually measured through license revenue from IP licensing and income from industryfunded research, including contracts, research collaboration, consultancy, renting of equipment and facilities, and professional development and education programs (HEFCE 2017). Other benefits that are difficult to measure in financial terms have not been measured on a consistent basis, although they have been examined in the academic literature (Perkman et al. 2011). They include knowledge flows from firms to universities, information on interesting opportunities for research, including research of value for commercial applications, and job placements for graduates and $\mathrm{PhD}$ candidates. Potential costs include the costs of funding KTO activities, such as marketing and managing IP, evaluating the commercial potential of inventions, and patenting and other legal costs. Nonfinancial costs include disruptions to the research function of universities, such as delays in publication, a decline in academic involvement in basic research, or the diversion of academic time to patenting and licensing activities (Thursby and Thursby 2007).

\subsubsection{Data on Policies and Practices to Support Knowledge Transfer}

Data on the policies and practices that public research organizations use to support knowledge transfer can be used to evaluate and identify 
the factors that support or hamper knowledge transfer activities. These include both policies at the national level and policies and practices that are implemented at the institutional level for each university or public research institute. Useful data on policies and practices implemented by national or regional governments or the institution itself can be obtained from surveying KTOs. International comparability in data for policies and practices is required for multicountry analyses of the factors that influence knowledge transfer performance.

Many countries have introduced legislation on the ownership of IP produced by public research organizations, the establishment of KTOs, whether or not researchers should be provided financial incentives if a discovery is licensed, and, in some countries, the percentage of license income that researchers should receive; and whether or not academics at universities must file invention disclosure reports. For Europe, Geuna and Rossi (2011) found that it is difficult to disentangle the effects of changes in IP ownership on academic patenting activities from the effects of concurrent transformations in the institutional, cultural, and organization landscape surrounding knowledge transfer. National policies that are directed toward businesses can also encourage knowledge transfer, such as subsidies for firms to collaborate on innovation with university or public research institute partners, or government reimbursement "vouchers" that firms can give to researchers in return for assistance with practical problems. Information on national policies is valuable for understanding the factors that shape national knowledge transfer activities.

Practices are often based on written regulations or guidelines, but are either not legally required (in the case of a guideline), or, if based on regulation, not enforced. For example, policies on the ownership of IP are usually established at the national level and universities are legally required to follow them. In contrast, a national or institutional regulation requiring academics to file an invention disclosure report for a discovery with potential commercial value is often closer to a practice, with few or any penalties for academics that fail to file.

Data collection for policies and practices is less developed than for knowledge transfer activities, as shown in Table 12.2 for the six case study countries. China only provides data on national regulations on the assumption that these are implemented by all public research organizations. Neither Brazil nor Germany collects data on policies and practices for large samples of public research organizations. 
Table 12.2 Data collected for IP policies at the national $(\mathcal{})$ or institutional $(\checkmark \checkmark)$ level (results for six countries)

\begin{tabular}{|c|c|c|c|c|c|c|}
\hline & China & Brazil & $\begin{array}{l}\text { South } \\
\text { Africa }\end{array}$ & UK & Korea & Germany $^{1}$ \\
\hline $\begin{array}{l}\text { Incentives for } \\
\text { academics to disclose } \\
\text { inventions to support } \\
\text { knowledge transfer }\end{array}$ & $\checkmark$ & & & $\checkmark \checkmark$ & $\checkmark \checkmark$ & \\
\hline $\begin{array}{l}\text { Promotion of } \\
\text { knowledge transfer } \\
\text { opportunities to the } \\
\text { business sector }\end{array}$ & $\checkmark$ & & & & & \\
\hline $\begin{array}{l}\text { Written rules or } \\
\text { guidelines for } \\
\text { knowledge transfer }\end{array}$ & $\checkmark$ & & $\checkmark$ & & $\checkmark \checkmark$ & \\
\hline $\begin{array}{l}\text { Written rules or } \\
\text { guidelines made } \\
\text { publicly available }\end{array}$ & $\checkmark$ & & $\checkmark$ & & & \\
\hline $\begin{array}{l}\text { Rules for publication } \\
\text { delays to support IP } \\
\text { licensing }\end{array}$ & & & $\checkmark \checkmark$ & & & \\
\hline $\begin{array}{l}\text { Academics permitted to } \\
\text { take leave to work at } \\
\text { a firm or startup }\end{array}$ & $\checkmark$ & & & $\checkmark \checkmark$ & & \\
\hline $\begin{array}{l}\text { Goals of KTOs for } \\
\text { knowledge transfer }\end{array}$ & $\checkmark$ & & $\checkmark \checkmark$ & $\checkmark \checkmark$ & $\checkmark \checkmark$ & \\
\hline
\end{tabular}

Source: National experts responding to a WIPO survey on data collection ${ }^{1}$ Some data have been collected on a sporadic basis by private-sector organizations or academics for a selected number of leading public research organizations.

Most of the research on policies and practices has primarily focused on IP-mediated knowledge transfer, although some has also evaluated research contracts and consulting. Knowledge transfer via licensing is influenced by IP regulations (Baldini et al. 2006), rules for exclusive licensing, licensing practices (Okamuro and Nishimura 2013; Shen 2016), the involvement of academics in contract or consulting research (Weckowska 2015), and financial and nonfinancial incentives (Chatterjee and Sankaran 2015) for academics to participate in knowledge transfer. 
Policies that contribute to the establishment of startups include dedicated programs (support for developing business plans, etc.) and facilities (such as an incubator) to support startups (Berbegal-Mirabent et al. 2015; Muscio et al. 2016), and employment conditions that permit academics to take leave to work with startups. The share of license revenue allotted to inventors acts as an alternative source of income for startups and can reduce the interest of academics in participating in them (Markman et al. 2004; Barjak et al. 2015).

Table 12.3 summarizes useful metrics on policies and practices for data collection at the level of the university or public research institute. The

Table 12.3 Metrics at the institutional level for policies and practices to support knowledge transfer

\begin{tabular}{|c|c|c|}
\hline \multirow[b]{2}{*}{ Metric } & \multicolumn{2}{|c|}{ Measurement level } \\
\hline & Nominal & Ordinal/interval \\
\hline \multicolumn{3}{|l|}{ Key policy metrics } \\
\hline $\begin{array}{l}\text { Importance of goals for knowledge } \\
\text { transfer (earn income, support } \\
\text { regional development, marketing } \\
\text { university capabilities, etc.) }\end{array}$ & & $\checkmark$ \\
\hline $\begin{array}{l}\text { Ownership rules for IP developed by } \\
\text { public research organizations, } \\
\text { including ownership of IP resulting } \\
\text { from public research organization- } \\
\text { firm research agreements }\end{array}$ & $\checkmark$ & \\
\hline $\begin{array}{l}\text { Financial incentives for researchers to } \\
\text { support knowledge transfer: } \\
\text { (incentives for invention disclosure, } \\
\text { share of revenue from licenses, } \\
\text { research contracts, etc.) }\end{array}$ & $\checkmark$ & $\checkmark$ \\
\hline $\begin{array}{l}\text { Rules for consulting (time limits on } \\
\text { consulting, how income is } \\
\text { distributed between the academic, } \\
\text { research group, etc.) }\end{array}$ & $\checkmark$ & $\checkmark$ \\
\hline $\begin{array}{l}\text { Nonfinancial incentives for researchers } \\
\text { for different types of knowledge } \\
\text { transfer (reputation, job } \\
\text { promotion, etc.) }\end{array}$ & $\checkmark$ & \\
\hline
\end{tabular}


Table 12.3 (cont.)

\begin{tabular}{|c|c|c|}
\hline \multirow[b]{2}{*}{ Metric } & \multicolumn{2}{|c|}{ Measurement level } \\
\hline & Nominal & Ordinal/interval \\
\hline $\begin{array}{l}\text { Researcher permitted to temporarily } \\
\text { work with a licensee/spinoff, firm } \\
\text { involved in collaborative research } \\
\text { (including maximum length) }\end{array}$ & $\checkmark$ & $\checkmark$ \\
\hline $\begin{array}{l}\text { Presence and amount of supporting } \\
\text { infrastructure for startups and } \\
\text { spinoffs (incubator, science } \\
\text { park, etc.) }\end{array}$ & $\checkmark$ & $\checkmark$ \\
\hline $\begin{array}{l}\text { Presence of different types of financial } \\
\text { support (funding for KTOs, seed } \\
\text { funding, etc.) }\end{array}$ & $\checkmark$ & $\checkmark$ \\
\hline \multicolumn{3}{|l|}{ Supplementary policy metrics } \\
\hline $\begin{array}{l}\text { Requirement or incentives for } \\
\text { researchers to assist } \\
\text { commercialization (i.e., work with } \\
\text { a licensee, research contract partner) }\end{array}$ & $\checkmark$ & \\
\hline $\begin{array}{l}\text { Requirement for researchers to report } \\
\text { invention disclosures }\end{array}$ & $\checkmark$ & \\
\hline $\begin{array}{l}\text { Presence of written rules or guidelines } \\
\text { for licensing, including publicly } \\
\text { available model contracts }\end{array}$ & $\checkmark$ & \\
\hline Presence of flexible rules for licensing & $\checkmark$ & \\
\hline $\begin{array}{l}\text { Presence of written rules for the } \\
\text { conditions for an exclusive or } \\
\text { nonexclusive license }\end{array}$ & $\checkmark$ & \\
\hline $\begin{array}{l}\text { Policy for publication delays (including } \\
\text { maximum length) to support } \\
\text { patenting, licensing, or collaborative } \\
\text { research }\end{array}$ & $\checkmark$ & $\checkmark$ \\
\hline $\begin{array}{l}\text { KTO or other public research } \\
\text { organization activities to promote IP } \\
\text { or staff capabilities to the business } \\
\text { sector }\end{array}$ & $\checkmark$ & \\
\hline
\end{tabular}

Source: Authors 
main purpose of these metrics is for monitoring and policy evaluation. Some of the data need only be collected at the nominal level (yes or no), whereas other data can be collected on an interval level (percent of royalties provided to inventors or length of academic leave to work with a firm) or ordinal level (importance of different goals for knowledge transfer). The table is divided into key and supplementary metrics, based on the importance, as identified in the literature, of each policy or practice. Sample questions for measuring many of these policies, derived from a 2016 WIPO survey, are provided in the Technical Annex.

\subsection{Surveys of Academics (Researchers) at Public Research Organizations}

Surveys of academics can provide several types of data that cannot be obtained through surveys of KTOs or university administrations: the use and importance of informal knowledge channels compared to other channels and the influence on knowledge transfer activities and outcomes of the personal characteristics of academics and organizational factors at the departmental or research group level. The main purpose of collecting data from academics is for monitoring and policy evaluation.

Compared to research using data obtained from KTOs, there are considerably fewer empirical studies on the engagement of academics in activities to transfer knowledge to firms. A 2013 systematic literature review of studies on academic engagement published between 1980 and 2011 identified twenty-five separate surveys of academics in thirteen countries: ten surveys in the U.S., four in the United Kingdom, two surveys in each of the Netherlands and Germany, and one survey in each of Spain, Chile, South Africa, Italy, Norway, Ireland, Sweden, Belgium, and Japan (Perkman et al. 2013). In addition, the study reported on two studies with over thirty interviews. The studies focused on engagement through contractual, collaborative, and consulting agreements and collected data on four types of factor, as summarized in Table 12.4. The first three factors influence knowledge transfer activities while the fourth measures the effects of knowledge transfer.

Relevant data to collect in surveys of academics include the number or percentage of different types of academic staff involved in knowledge transfer through informal, contractual, and IP-mediated channels; barriers to interactions, including "cost" factors such as secrecy and concern over academic freedom (see Table 12.5); and the goals for participation in each type of channel. In addition, academic surveys can provide relevant 
Table 12.4 Data collected in previous surveys of academic engagement

\begin{tabular}{|c|c|}
\hline Factor & Data \\
\hline Characteristics of academics & $\begin{array}{l}\text { Gender, age, seniority, previous } \\
\text { commercialization experience, } \\
\text { government grants awarded, and } \\
\text { scientific productivity }\end{array}$ \\
\hline Organizational factors & $\begin{array}{l}\text { Quality of the university or department, } \\
\text { organizational support, incentives, } \\
\text { organizational experience with } \\
\text { commercialization, peer effects }\end{array}$ \\
\hline Institutional factors & $\begin{array}{l}\text { Discipline or field, national regulations/ } \\
\text { policies }\end{array}$ \\
\hline Outcomes & $\begin{array}{l}\text { Scientific productivity (publications, } \\
\text { patents), commercial productivity, } \\
\text { shift to applied research, secrecy, } \\
\text { collaborative behavior, teaching }\end{array}$ \\
\hline
\end{tabular}

Source: Based on Perkman et al. 2013

information on the types of partner, such as firms, government organizations, and nonprofits. An example of good practice is the large 2008-9 survey of 22,556 UK academics active in teaching or research (Abreu and Grenevich 2013; Abreu et al. 2016; Zhang et al. 2016). ${ }^{6}$ Due to the use of a representative sample, this study was able to determine that more academics interact with government organizations (53 percent) than with firms (41 percent) (Hughes and Kitson 2012), that academics in regional areas are more intensively involved in university-industry linkages than academics in the metropolitan regions, and that teaching-oriented universities are also very active in these linkages (Zhang et al. 2016).

The main challenge for surveying academics is to reduce the costs of surveying. A common method is to construct a sample that excludes academics who are unlikely to develop knowledge with commercial potential and consequently have little or no experience with knowledge transfer. A solution is to focus surveys on academics in applied science

${ }^{6}$ The survey questionnaire does not appear to be available online, but the questions can be reconstructed using the tables in the following URL: https://eprints.soton.ac.uk/357117/1/ AcademicSurveyReport.pdf. 
Table 12.5 Knowledge transfer metrics from surveys of academics and firms

Academics

Firms

Incentives for participation in knowledge transfer

Financial

Promotion

Previous experience with knowledge transfer

Informal (personal contacts, conferences/

meetings)

Training

Use of advanced equipment/facilities

Research contracts or consultancy

Collaborative research

Licensing IP

Barriers/reasons not to participate

University rules for knowledge transfer

Lack of time (teaching responsibilities etc.)

Research of little interest

Concern over publication/delays

Underdeveloped technology

Difficulties in find right licensee

Costs to evaluate commercial potential

Costs to prepare legal matters involving IP rights

Potential loss of technological/competitive edge

Prices charged by licensor too high

Goals for participation

Acquire leading-edge research results

Freedom-to-operate

Close technological gaps

Funding from businesses for research, $\mathrm{PhD}$ candidates etc.

Better insight to commercialization opportunities

Economic effects

New knowledge from public research

organizations incorporated in products and

processes

Sales share/imputed savings due to knowledge from public research organizations

Source: Authors 
departments, or on research-intensive universities who are likely to have experience in developing commercially valuable knowledge (Perkmann et al. 2013), or by selecting the departmental heads for technology disciplines, principal investigators on research projects, the heads of research groups (Van Dierdonck et al. 1990), academics who have been granted a patent, or academics who have founded a firm (Agiar-Díaz et al. 2016; Czarnitzki et al. 2016).

The disadvantage of these methods for selecting academics for surveys on knowledge transfer is that they can undervalue the opportunities for knowledge transfer from teaching-oriented universities or from the social sciences and result in inaccurate measures of the disadvantages of different types of knowledge transfer activity. For example, the possible disadvantages of close university-industry linkages include a loss of academic freedom (ability to choose to conduct basic research or research of low commercial interest) and restrictions or delays on publication due to the interest in commercial partners in secrecy (Van Looy et al. 2004; Tartari and Breschi 2012; Muscio and Pozzali 2013). The importance of publication delays is likely to be greatest for early career researchers such as $\mathrm{PhD}$ candidates and post-doctorates that need to rapidly build up a list of publications. Yet this possible effect will be missed entirely in studies that focus on the heads of research groups or departments. This could be one reason why a study of departmental heads finds that publication delays are given a low importance ranking as a barrier to collaboration with industry, whereas impacts on the choice of research is given a much higher importance ranking (Muscio and Pozzali 2013).

\subsection{Surveys of Firms}

Surveys of firms can complement surveys of academics. Both types of survey can include similar questions and thereby identify differences in the perspectives of academics and firm managers on knowledge transfer activities. Data from firms can be used for benchmarking performance (if data are collected on economic effects), monitoring and policy evaluation.

Survey research on firms consistently points to the importance of open science methods of knowledge transfer in high-, medium-, and lowincome countries, although in middle-income countries in Asia contractual methods are often more commonly cited than open science (Siegel et al. 2003; De Fuentes and Dutrénit 2012; Frietas et al. 2013; Grimpe and 
Hussinger 2013; Okamuro and Nishimura 2013; Dutrénit and Arza 2015; Kafouros et al. 2015; Kruss et al. 2015; Schiller and Lee 2015). A possible explanation is the importance of contractual relationships to building innovative capacity and problem-solving abilities among firms.

Firms in low- and middle-income countries in Africa, Asia, and Latin America were surveyed on their use of knowledge channels in an internationally coordinated study that used the same questionnaire (Albuquerque et al. 2015). In two low-income countries (Uganda and Nigeria) informal methods dominate (Kruss et al. 2015), whereas in middle-income countries in Asia (Malaysia, Thailand, and China) the most common methods are consultancy and research contracts (Schiller and Lee 2015). In four middle-income Latin American countries (Argentina, Brazil, Mexico, and Costa Rica) both contracts and informal methods are more frequently used than IP-mediated methods (Dutrénit and Arza 2015). These results indicate that surveys of firms are of value to identifying the relative importance of different knowledge channels.

Surveys of firms face similar issues to those of surveys of academics: to reduce costs, the 80-90 percent of firms that are unlikely to source knowledge from public research organizations in a defined time period are usually excluded. Targeting can be improved by limiting surveys to firms in specific sectors where the use of knowledge produced by public research organizations is more likely (Bekkers et al. 2008), such as life science firms, or excluding firms with few employees.

Surveys that follow the Oslo Manual guidelines (OECD/Eurostat 2018) for measuring innovation in the business sector, such as the European Community Innovation Survey (CIS), often collect relevant data on university-firm linkages. For example, the CIS includes a question on the importance of information obtained from universities to the firm's innovation activities and a question on collaboration with universities. These surveys consistently find that universities are an important source of information to less than 10 percent of firms, but their importance is higher for large firms and for firms in sectors such as pharmaceuticals that draw extensively on science. R\&D surveys, although limited to R\&D-performing firms that account for less than half of innovative firms, can also include relevant questions, such as business expenditures for $\mathrm{R} \& \mathrm{D}$ that is contracted out to universities or government laboratories.

Table 12.5 identifies useful indicators that can be obtained from surveys of academics and firms. Many of the indicators are applicable to both academics and firms, although some of the questions may need to 
be adapted to the type of respondent. For instance, questions on financial incentives for firms to source knowledge from public research organizations could list specific policy instruments, such as vouchers, subsidies for collaboration, etc. To improve recall quality, these surveys need to be limited to a defined period of time of between one and three years (OECD/Eurostat 2018) or refer to specific research outputs or inventions.

The benefits of knowledge transfer for firms consist of solutions for known problems (mostly relevant to contractual or collaborative research) (Perkman et al. 2011), improvements in innovative capabilities (De Fuentes and Dutrénit 2012), innovative products and processes, and earned income or cost savings from these innovations. Knowledge transfer activities can increase costs for firms when licenses are required for types of knowledge that were previously available at no cost or as part of open science. Otherwise, most of the costs incurred by firms are opportunity costs.

Several additional details to the questions listed in Table 12.5 for economic effects would assist research on the economic benefits for businesses. Relevant questions include (1) whether new knowledge obtained through public research organization research contracts, public research organization licensing, or informal public research organization contacts was implemented in products and processes, (2) the total sales revenue from these products and the imputed savings from these processes, (3) the fraction of sales revenue/cost savings attributed to knowledge obtained from public research organizations, (4) the sector of application for products and processes, (5) expectations for the next two years for a change in sales/cost savings for these products and processes, and (6) total sales revenues from all products (required to estimate the share of sales from products containing knowledge obtained from public research organizations).

\subsection{Publicly Available (Big) Data}

Big data are collected automatically and available in electronic form. Patent records, Google citations, and administrative data collected by governments for taxation and other purposes are all examples of big data. Another form that is attracting increasing attention is the use of Internet data, such as web-scraping to identify innovation activities within firms or university startups (NESTA 2018).

Big data such as patent databases can be used to directly produce knowledge transfer metrics or combined with data from KTOs or 
academic surveys. For example, patent data can be used to identify the share of patents produced by academics that are owned by firms or by universities (Geuna and Rossi 2011). Big data on publications, patents, or administrative data can also be linked to university-level data on a range of knowledge transfer activities and outcomes (Van Looy et al. 2011; Berbegal-Mirabent and Sabate 2015). An example is to evaluate the relationship between regional firm capabilities and knowledge transfer activities. Firm-level capabilities can be estimated from regional administrative data on $R \& D$ expenditures, business sector $R \& D$ intensities, and industrial structure (for instance, the share of private-sector output in low-, medium-, and high-technology sectors).

The use of web-scraping to produce metrics for innovation, including knowledge transfer, is in its infancy, but experimentation in this area is expected to produce useful results in the future. Woltmann (2018) used web-scraping methods to try to identify knowledge transfer from the Technical University of Denmark to firms via publications and university-owned patents. Text mining was used to identify similarities in the text of business websites and university patents and publications. The assumption is that firms that benefit from these two types of university output will replicate relevant text on their corporate webpages. The method identified a small number of matches with business websites, with matching better for publications than for patents.

\subsection{Metrics for the Systemic Benefits of Knowledge Transfer}

The main policy goal for knowledge transfer is to support the systemic economic and social benefits of knowledge transferred to firms, individuals, and governments and the subsequent effects at the municipal (Felsenstein 1996), regional, or national level (Cheah 2016). A review of academic research on the economic contribution of publicly funded basic research concludes that it is positive and substantial (Salter and Martin 2001), but it is a challenge to link specific knowledge transfer channels to systemic outcomes. Research using patent citation data has found positive benefits from academic research on the number of corporate patents in technology-based sectors (Verspagen 1999), which could result in an increase in innovative products and processes, but, in other sectors, knowledge transfer via patents is likely to be less important since the majority of innovations are not patented (Arundel and Kabla 1998). For a region or country, the greatest contributor to systemic benefits could be via non-IP-mediated channels such as research contracts, open science, 
and the employment of individuals with university qualifications (Roessner et al. 2013).

Collaboration between government, academia, and industry is considered to be of critical importance in enhancing regional economic and social development (Etzkowitz and Leydesdorff 2000; Klofsten et al. 2010; Urbano and Guerrero 2013). The effectiveness of tripartite collaboration has, however, been questioned, as many regions have failed to obtain expected benefits from knowledge transfer in terms of innovation, GDP, and employment (Asheim and Coenen 2005; McAdam et al. 2012). In order to address this challenge, recent policy initiatives identify the need for a more open science approach that includes social innovators involved at various stages throughout the knowledge transfer process (Wilson 2012). The inclusion of social innovators (Leydesdorff 2011) reflects the increasing importance placed on knowledge transfer to meet societal needs (Bozeman et al. 2015). It also emphasizes that knowledge transfer occurs not only between public research organizations and firms but also between public research organizations, governments, and nonprofit organizations.

Estimates of systemic financial benefits require data from surveys of firms, nonprofits, and government organizations on the uptake, application, and economic value of knowledge produced by public research organizations. This is very difficult to estimate because many innovations are built on multiple sources of knowledge. For all knowledge transfer channels, estimates need to obtain data from surveys of managers, but managers are unlikely to be able to estimate the diffuse effects of open science on their organization and often may not know or recognize the role of open science on key products (Mazzucato 2015).

A more feasible approach is to focus on formal knowledge transfer channels. Data on the economic impacts of knowledge transfer on government organizations or firms (using the data described in Section 12.5) from a random sample could be extrapolated to specific sectors. For contracts, this would require data on which contracts led to commercialized products or processes, the sector of application, and the sales revenue earned by the firm (or the value of services provided by governments) for products or imputed savings from processes. The reliability of this approach depends on the willingness of managers to volunteer information that could be commercially confidential and their ability to provide accurate retrospective information over a number of years.

Estimates of financial benefits are perhaps easiest to obtain for public research organization spinoffs on the heroic assumption that all future 
sales derive from the initial development of knowledge obtained from the public research organization at the time of establishment (Vincett 2010).

Other researchers have estimated the effect of public research organization research on GDP by combining data on running royalties (percentage of total sales) from licensed IP with estimates of the running royalty rate and the value-added components of sales from sectoral input-output models. For example, a study for the U.S. uses AUTM licensing data to estimate output from 1996 to 2010 for assumed royalty rates of 2, 5, and 10 percent. The estimated contribution to GDP in 2009 from licensing varied from USD 70.4 billion at a 2 percent royalty rate to USD 16.4 billion for a 10 percent royalty rate (Roessner et al. 2013). Although the former estimate exceeds total university R\&D expenditures in 2009 of USD 55 billion, it is important to note that the estimated contribution is based on IP developed over multiple years before 2009. The disadvantage of this method is that it is only likely to account for a small percentage of the benefits from all knowledge transfer channels.

A regular survey aimed at universities and public research organizations conducted by the State Intellectual Property Office (SIPO) of the People's Republic of China asks patent applicants about the knowledge transfer process and commercialization method and, for patented products, the total income earned from product sales. ${ }^{7}$ This information is potentially of great interest, but patent applicants may not always know the answers to questions on commercialization or income earned from product sales.

Nonfinancial systemic benefits are diverse and include improved quality of life from new therapeutic treatments for diseases, new business opportunities, and social benefits such as new educational and entertainment platforms on the Internet. These types of benefit are rarely measured, in part due to the difficulty in attaching a financial value to social outcomes. The default is to use case studies to highlight the social benefits of university research (Kearnes and Wienroth 2011). The AUTM, as part of its "better world project," includes case-study examples in its annual licensing reports of the social and economic impacts of licensed university inventions. In many cases, this is a practical solution to illustrating the range of different types of both financial and nonfinancial benefit for

7 See, for the first public release, http://english.sipo.gov.cn/news/official/201608/ t20160802_1284168.html. 
specific inventions based on knowledge produced by public research organizations.

Systemic costs are difficult to identify and estimate since they are based on "what if" situations involving unmeasurable counterfactuals. For example, a theoretical social cost would occur if academics neglect basic research with high benefits over the long term in order to pursue applied research that meets short-term industry needs.

\subsection{Conclusions}

Knowledge transfer metrics are required for benchmarking changes in performance over time and for econometric analysis to evaluate the effectiveness of policies and practices. In both high- and middleincome countries most of the existing metrics focus on IP-mediated knowledge transfer, such as the number of patents produced by universities and the amount of license income earned. The premise of this chapter is that this is insufficient - both because it sends an erroneous signal to policymakers and administrators in universities and public research institutes that IP-mediated knowledge transfer is the optimum form, resulting in distortions in incentives, and also because it is not fit for purpose, with most knowledge transferred by means of other formal and informal channels. Consequently, a comprehensive set of knowledge transfer metrics to guide policy requires collecting metrics for a diverse range of knowledge transfer channels.

In addition to the basic metrics for IP-mediated knowledge transfer (see Chapter 2), this chapter recommends collecting metrics for other formal channels (collaboration, contracts, consultancy, etc.) from universities and public research institutes (for instance, by surveying KTOs) and metrics for informal knowledge transfer methods from surveys of academics and firms. Such surveys as these can also collect useful data on the goals of academics and firms in participating in knowledge transfer and the barriers that they face. Surveys of firms in middle-income countries should also include metrics to identify differences in the use of and need for knowledge transfer by firm capabilities (see also Chapter 11 ) and the types of financial incentive that they receive from government, such as vouchers. The main topics to be covered through data collection are identified through several tables in this chapter.

Another feature of a comprehensive set of metrics is the need to collect institutional data on policies and practices for use in policy evaluation and monitoring. This is essential for determining which factors best 
promote knowledge transfer and support the absorptive capacity of firms under different conditions. For example, the set of factors that promote knowledge transfer are likely to differ depending on the outcome (startup establishments versus adoption by existing firms), interactions with other policies, firm capabilities, and the industrial structure of a country or region.

Data for all types of formal knowledge channel should be collected on an annual basis from universities and public research institutes in order to encourage them to establish rigorous administrative records for these types of knowledge transfer activity. The marginal cost of annual data collection is also likely to be very low compared to the cost of biennial or less frequent surveys. In contrast, surveys of academics and firms are expensive and consequently these surveys only need to be conducted every three to five years, possibly by contracting out surveys to academics with expertise in knowledge transfer. Data on policies and practices tend to change slowly and therefore could be collected every three to five years from KTO surveys, although an open question could be included in annual surveys of KTOs to identify recent changes.

\section{References}

Abreu, M., P. Demirel, V. Grenevich, and M. Karatas-Ozkan (2016). "Entrepreneurial practices in research-intensive and teaching led universities." Small Business Economics, 47: 695-717.

Abreu, M. and V. Grenevich (2013). "The nature of academic entrepreneurship in the UK: Widening the focus on E activities." Research Policy, 42: 408-22.

Agiar-Díaz, I., N.L. Díaz-Díaz, J.L. Ballesteros-Rodríguez, and P. De Sáa-Pérez (2016). "University-industry relations and research group productions: Is there a bidirectional relationship?” Industrial and Corporate Change, 25: 611-32.

Albuquerque, E., W. Suzigan, G. Kruss, and K. Lee (eds.) (2015). Developing National Systems of Innovation: University-Industry Interactions in the Global South. Cheltenham: Edward Elgar.

Arundel. A. and I. Kabla (1998). "What percentage of innovations are patented? Empirical estimates for European firms." Research Policy, 27: 127-41.

Asheim, B.T. and L. Coenen (2005). "Knowledge bases and regional innovation systems: Comparing Nordic clusters." Research Policy, 34: 1173-90.

AUTM (Association of University Technology Managers) (2016). Highlights of AUTM"s Canadian Licensing Survey FY2015, Oakbrook Terrace.

AUTM (Association of University Technology Managers) (2017). AUTM U.S. Licensing Activity Survey: FY2016, A Survey Report of Technology Licensing 
(and Related) Activity for U.S. Academic and Nonprofit Institutions and Technology Investment Firms, Oakbrook Terrace.

Baldini, N., R. Grimaldi, and M. Sobrero (2006). "Institutional changes and the commercialization of academic knowledge: A study of Italian universities' patenting activities between 1965 and 2002.” Research Policy, 35: 518-32.

Barjak, F., N. Es-Sadki, and A. Arundel (2015). "The effectiveness of policies for formal knowledge transfer from European universities and public research institutes to firms." Research Evaluation, 24: 4-18.

Bekkers, R. and I.M. Bodas-Freitas (2008). “Analysing knowledge transfer channels between universities and industry: To what degree to sectors also matter?"Research Policy, 37: 1837-53.

Belitski, M., A. Aginskaja, and R. Marozau (2019). "Commercializing university research in transition economies: Technology transfer offices or direct industrial funding?" Research Policy, 48: 601-15.

Berbegal-Mirabent, J., D.E. Ribeiro-Soriano, and J.L.S. Garcia (2015). “Can a magic recipe foster university spin-off creation?” Journal of Business Research, 68: 2272-8.

Berbegal-Mirabent, J. and F. Sabate (2015). "Balancing basic and applied research outputs: A study of the trade-offs between publishing and patenting." Technology Analysis \& Strategic Management, 27: 1143-58.

Bozeman, B., H. Rimes, and J. Youtie (2015). "The evolving state-of-the-art in technology transfer research: Revisiting the contingent effectiveness model." Research Policy, 44: 34-49.

Chatterjee, D. and B. Sankaran (2015). "Commercializing academic research in emerging economies: Do organizational identities matter?” Science and Public Policy, 42: 599-613.

Cheah, S. "Framework for measuring research and innovation impact." Innovation: Management, Policy \& Practice, 18: 212-32.

Czarnitzki, D., T. Doherr, K. Hussinger, P. Schliessler, and A.A. Toole (2016). "Knowledge creates markets: The influence of entrepreneurial support and patent rights on academic entrepreneurship." European Economic Review, 86: 131-46.

De Fuentes, C. and G. Dutrénit (2012). "Best channels of academia-industry interaction for long-term benefit." Research Policy, 41: 1666-82.

Dutrénit, G. and V. Arza (2015). "Features of interactions between public research organizations and industry in Latin America: The perspective of researchers and firms.” In E. Albuquerque, W. Suzigan, G. Kruss, and L. Lee K (eds.), Developing National Systems of Innovation. Cheltenham: Edward Elgar.

Etzkowitz, H. and L. Leydesdorff (2000). "The dynamics of innovation: from national systems and 'mode 2' to a triple helix of university-industrygovernment relations.” Research Policy, 29: 109-23. 
Felsenstein, D. (1996). “The university in the metropolitan arena: Impacts and public policy implications." Urban Studies, 33: 1565-80.

Finne, H., A. Arundel, G. Balling, P. Brisson, and J. Erselius (2009). Metrics for Knowledge Transfer from Public Research Organisations in Europe. Report from the European Commission's expert group on knowledge transfer metrics. Luxembourg: Office for Official Publications of the European Communities.

Freitas, I.M.B., A. Geuna, and F. Rossi (2013). "Finding the right partners: Institutional and personal modes of governance of university-industry interactions." Research Policy, 42: 50-62.

Geuna, A. and F. Rossi (2011). "Changes to university IPR regulations in Europe and the impact on academic patenting." Research Policy, 40: 1068-76.

Grimpe, C. and K. Hussinger (2013). "Formal and informal knowledge and technology transfer from academia to industry: Complementarity effects and innovation performance." Industry and innovation, 20: 683-700.

Hayer, C.S. (2016). "A trajectory of early-stage spinoff success: The role of knowledge intermediaries within an entrepreneurial university ecosystem.” Small Business Economics, 47: 633-56.

HEFCE (Higher Education Funding Council for England) (2017). Higher Education - Business and Community Interaction Survey 2015-16. London: HEFCE.

Holi. M., R. Wickramasinghe, and M. van Leeuwen (2008). Metrics for the Evaluation of Knowledge Transfer Activities at Universities. Cambridge: Library House.

Hughes, A. and M. Kitson (2012). "Pathways to impact and the strategic role of universities: New evidence on the breadth and depth of university knowledge exchange in the UK and the factors constraining its development." Cambridge Journal of Economics, 36: 723-50.

Jensen, P.H., A. Palangkaraya, and E. Webster (2009). "A guide to metrics on knowledge transfer from universities to businesses and industry in Australia." Knowledge Commercialisation Australasia, September.

Kafouros, M., C. Wang, P. Piperopoulis, and M. Zhang (2015). “Academic collaborations and firm innovation performance in China: The role of region-specific institutions." Research Policy, 44: 803-17.

Kearnes, M. and M. Wienroth (2011). "Tools of the trade: UK research intermediaries and the politics of impacts.” Minerva, 49: 153-74.

Klofsten, M., P. Heydebreck, and D. Jones-Evans (2010). “Transferring good practice beyond organizational borders: Lessons from transferring an entrepreneurship programme." Regional Studies, 44: 791-9.

Kruss, G., J.O. Adeoti, and D. Nabudere (2015). "Bracing for change: Making universities and firms partners for innovation in sub-Saharan Africa." In 
E. Albuquerque, W. Suzigan, G. Kruss, and K. Lee (eds.), Developing National Systems of Innovation. Cheltenham: Edward Elgar.

Leydesdorff, L. (2011). “The triple helix, quadruple helix, and an N-tuple of helices: Explanatory models for analyzing the knowledge-based economy?"Journal of the Knowledge Economy, 3: 25-35.

Link, A.N., D.S. Siegel, and B. Bozeman (2007). "An empirical analysis of the propensity of academics to engage in informal university technology transfer." Industrial and Corporate Change, 16: 641-55.

Lockett, A., M. Wright, and A. Wild (2015). "The institutionalization of third stream activities in UK higher education: The role of discourse and metrics." British Journal of Management, 26: 78-92.

Markman, G.D., P.T Gianiodis, P.H. Phan, and D.B. Balkin (2004). "Entrepreneurship from the Ivory tower: Do incentive systems matter?" Journal of Technology Transfer, 29: 353-64.

Mazzucato, M. (2015). The Entrepreneurial State, US ed. New York: Public Affairs.

McAdam, R., K. Miller, M. McAdam, and S. Teague (2012). “The development of university technology transfer stakeholder relationships at a regional level: Lessons for the future." Technovation, 32: 57-67.

Muscio, A., D. Quaglione, and L. Ramaciotti (2016). "The effects of university rules on spinoff creation: The case of academia in Italy.” Research Policy, 45: 1386-96.

Muscio, A. and A. Pozzali (2013). "The effects of cognitive distance in university-industry collaborations: Some evidence from Italian universities." Journal of Technology Transfer, 38: 486-508.

NESTA (2018). European Innovation Scoreboard 2018: Exploratory Report B: Toward the Incorporation of Big Data in the European Innovation Scoreboard. Luxembourg: European Commission.

OECD/Eurostat (2018). Oslo Manual: Guidelines for Collecting, Reporting and Using Data on Innovation, 4th edn. Luxembourg: OECD Publishing Paris/Eurostat.

Okamuro, H. and J. Nishimura (2013). "Impact of university intellectual property policy on the performance of university-industry research collaboration." Journal of Technology Transfer, 38: 273-301.

Perkman, M., A. Neely, and K. Walsh (2011). "How should firms evaluate success in university-industry alliances? A performance measurement system." R\&D Management, 41: 202-16.

Perkman, M., V. Tartari, and M. McKelvey (2013). "Academic engagement and commercialisation: A review of the literature on university-industry relations." Research Policy, 42: 423-42.

Roessner, D., J. Bond, S. Okubo, and M. Planting (2013). "The economic impact of licensed commercialized inventions originating in university research.” Research Policy, 42: 23-34.

Rosli, A. and F. Rossi (2014). Explaining the Gap between Policy Aspirations and Implementation: The Case of University Knowledge Transfer Policy in the 
United Kingdom. Working Paper no. 20. CIMR Research Working Paper Series. London: Birkbeck College.

Rossi, F. and R.A. Rosli (2015). "Indicators of university-industry knowledge transfer performance and their implications for universities: Evidence from the United Kingdom." Studies in Higher Education, 40: 1970-91.

Salter, A.J. and B.R. Martin (2001). "The economic benefits of publicly-funded basic research: A critical review." Research Policy, 30: 509-32.

Schiller, D. and K. Lee (2015). "Are university-industry links meaningful for catch up? A comparative analysis of five Asian countries." In E. Albuquerque, W. Suzigan, G. Kruss, and K. Lee (eds.), Developing National Systems of Innovation. Cheltenham: Edward Elgar.

Shen, Y.-C. (2003). "Identifying the Key Barriers of University-Industry Linkage in Taiwan.” Paper presented at ISPIM Innovation Forum, Boston, March 13-16, 2016. Siegel, D.S., D. Waldman, and A. Link (2003). "Assessing the impact of organizational practices on the relative productivity of university technology transfer offices: An exploratory study." Research Policy, 32: 27-48.

Sigurdson, K., C.M. Sa, and A. Kretz (2015). "Looking for the street light: Limitations of mainstream technology transfer indicators." Science and Public Policy, 42: 632-45.

Tartari, V. and S. Breschi (2012). "Set them free: Scientists' evaluations of the benefits and costs of university-industry research collaboration." Industrial and Corporate Change, 21: 1117-47.

Thursby, G. and M.C. Thursby (2007). "University licensing." Oxford Review of Economic Policy, 23: 620-39.

Urbano, D. and N. Guerrero (2013). "Entrepreneurial universities: Socioeconomic impacts of academic entrepreneurship in a European context." Economic Development Quarterly, 27: 40-55.

Van Dierdonck, R., K. Debackere, and B. Engelen (1990). "University-industry relationships: How does the Belgian academic community feel about it?" Research Policy, 19: 551-66.

Van Looy, B., P. Landoni, J. Callaert, B. Van Pottelsberghe, E. Sapsalis, and K. Debackere (2011). "Entrepreneurial effectiveness of European universities: An empirical assessment of antecedents and trade-offs." Research Policy, 40: 553-64.

Van Looy, B., Ranga, M., Callaert, J., K. Debackere, and E. Zimmermann (2004). "Combining entrepreneurial and scientific performance in academia: Towards a compounded and reciprocal Matthew-effect?" Research Policy, 33: 425-41.

Verspagen, B. (1999). "Large firms and knowledge flows in the Dutch R\&D System: A case study of Philips Electronics." Technology Analysis \& Strategic Management, 11: 211-33.

Veugelers, R. (2016). "The embodiment of knowledge: Universities as engines of growth." Oxford Review of Economic Policy, 32: 615-31. 
Vincett, P.S. (2010). "The economic impacts of academic spin-off companies and their implications." Research Policy, 39: 736-47.

Walshok, M.L. and J.D. Shapiro (2014). "Beyond tech transfer: A more comprehensive approach to measuring the entrepreneurial university." Advances in Entrepreneurship, Firm Emergence and Growth, 16: 1-36.

Weckowska, D.M. (2015) "Learning in university technology transfer offices: Transactions-focused and relations-focused approaches to commercialization of academic research." Technovation, 41-42: 62-74.

Wilson, T. (2012). A Review of Business-Industry Collaboration. London: Department for Business, Innovation, and Skills.

Woltmann, S. (2018). “Traces of Knowledge: Benchmarking Novel Text Mining Based Measurements." Proceedings of the DRUID Academy.

Zhang, Q., N.G. MacKenzie, D. Jones-Evans, and R. Huggins (2016). "Leveraging knowledge as a competitive asset? The intensity, performance and structure of universities entrepreneurial knowledge activities at a regional level." Small Business Economics, 47: 657-75. 